\title{
Country Size Effects for Foreign Trade. Are China and Russia Typical Large Economies?
}

\author{
Chen Jun ${ }^{1,}$, Oleksii A. Chugaiev ${ }^{2, b}$ \\ ${ }^{1}$ School of business, Jiangxi University of Science and Technology, Nanchang 330013, China \\ ${ }^{2}$ Institute of International Relations, Taras Shevchenko National University of Kyiv, Kyiv 04119, \\ Ukraine \\ achenjun_1013@hotmail.com, ${ }^{b}$ alxcv@ukr.net
}

Keywords: country size, large economies, international trade.

Abstract: The paper assesses the difference between small, medium-sized and large economies in foreign trade indicators (trade openness, balance, prices and growth). It supports the idea that foreign trade growth promotes growth, while there is usually no significant effect of trade openness, current account balance and terms of trade, considering foreign trade China and Russia behave according to the size of their economies.

\section{Introduction}

Country size can be an important determinant of international economic relations. This paper aims to check the hypothesis about dependence of foreign trade indicators on size of economy. The objective is extended by searching for optimal values of these indicators. We further extrapolate the results for the large economies of China and Russia.

\section{Previous research review}

Numerous studies proved the fact that large economies are less open to trade $\mathrm{e}^{1-5}$. E.g. P. Pieretti, S. Zanaj and B. Zou explain higher openness of small economies with small market size, worse availability of capital and labor ${ }^{6}$. At the same time P. Vujakovic questioned higher openness of small countries. They trade more with neighbor countries, thus small countries tend to be more regionalized than globalized. Meanwhile large countries (e.g. China) trade with both proximate and distant countries ${ }^{7}$. We assume that e.g. commodities traded $100 \mathrm{~km}$ away from the place of production are likely to be a part of domestic trade in case of large countries, while they are often constitute international trade in case of small countries. Imports to GDP ratio depends more on the country size than exports to GDP ratio ${ }^{8,9}$. The dependence is especially prominent in the economies with medium development level ${ }^{10}$. Thus, large economies have more chances to have a trade surplus (the effect for trade balance is also assessed in other studies ${ }^{11,12}$ ).

\section{Methodology}

The source of statistical data is the World Bank ${ }^{13}$. We use analysis of variance method (ANOVA) 
to estimate the economy size effects for international trade. All the countries in our sample are classified into three groups according to the purchasing power parity GDP:

- 31 large economies (GDP > worldwide mean \$640 billion);

- 63 medium-sized economies ( $\$ 640$ billion > GDP > worldwide median $\$ 70$ billion);

- 95 small economies (GDP < \$70 billion).

One-way ANOVA is used for estimating the effect of GDP size on foreign trade with F-test for difference in means, Levene's test for difference in variance and Fisher's least significance difference as a post-hoc criterion. The Kruskal-Wallis test and the median test are applied also as the data is not normally distributed. We also compare the trade indicators of China and Russia in 2016 with the mean values for large economies.

Two-way ANOVA is applied to estimate the effect of international trade on economic growth (real GDP per capita growth is used to control for the impact of population growth). We estimate the main effect of each binary trade variable and the interaction effect between the economy size and a trade variable. We also use regression analysis with the ordinary least square method to check robustness. The average annual GDP growth and trade indicators in 2009-2016 for each country are used for our analysis.

\section{Results}

Large economies with the average trade 65\% of the GDP are obviously less open to trade than smaller ones. Medium-sized economies are similar to small economies by the average values, but the median value for them differs from both small and large economies. If we consider merchandise trade only, both small and medium-sized economies are different from large economies. But in case of trade in services, small economies are much more open than large and medium-sized economies. The detailed results are described in the Table 1.

Table 1. Effects of economy size for international trade, 2009-16.

\begin{tabular}{|c|c|c|c|c|c|c|}
\hline \multirow[b]{2}{*}{ Indicator } & \multicolumn{3}{|c|}{ Values in various countries } & \multirow{2}{*}{$\begin{array}{c}\text { p-level } \\
\text { (F-test/ } \\
\text { K.-W. test / } \\
\text { median test) }\end{array}$} & \multicolumn{2}{|c|}{ Values in: } \\
\hline & $\begin{array}{c}\text { Small } \\
\text { economies }\end{array}$ & $\begin{array}{l}\text { Medium- } \\
\text { sized } \\
\text { economies }\end{array}$ & $\begin{array}{c}\text { Large } \\
\text { economies }\end{array}$ & & China & Russia \\
\hline Foreign trade, \% GDP & 102 & 95 & $65^{* * *}$ & $0,003 / \underline{0,000 / 0,000}$ & 37.1 & 46.3 \\
\hline Merchandise trade, \% GDP & 68 & 75 & $55^{* *}$ & $0,058 / \underline{0,002 / 0,040}$ & 32.9 & 36.9 \\
\hline Trade in services, \% GDP & $36^{* * *}$ & 22 & 12 & $0,000 / \underline{0,000 / 0,000}$ & 5.9 & 9.7 \\
\hline $\begin{array}{l}\text { Exports of goods and } \\
\text { services, \% GDP }\end{array}$ & 43 & 48 & $33 * *$ & $0,083 / \underline{0,022 / 0,013}$ & 19.6 & 25.7 \\
\hline $\begin{array}{l}\text { Imports of goods and } \\
\text { services, \% GDP }\end{array}$ & $59 * * *$ & $47 * * *$ & $32 * * *$ & $0,000 / \underline{0,000 / 0,000}$ & 17.4 & 20.6 \\
\hline Trade balance, \% GDP & $-15,7 * * *$ & 0,6 & 1,3 & $0,000 / \underline{0,000 / 0,000}$ & 2.2 & 5.2 \\
\hline $\begin{array}{l}\text { Current account balance, \% } \\
\text { GDP }\end{array}$ & $-6,4^{* *}$ & $-0,2$ & 0,4 & $0,010 / \underline{0,000 / 0,000}$ & 1.8 & 2.0 \\
\hline Exports growth, \% per year & $6,0 * *$ & 3,0 & 2,9 & $0,004 / \underline{0,008 / 0,041}$ & & 2.0 \\
\hline Imports growth, \% per year & $5,5 * *$ & 3,7 & 2,1 & $0,006 / \underline{0,013 / 0,043}$ & & -1.0 \\
\hline $\begin{array}{l}\text { Net barter terms of trade index } \\
\text { change, \% per year }\end{array}$ & $0,3^{* *}$ & $-1,1$ & $-0,5$ & $0,033 / \underline{0,086 / 0,537}$ & 1.4 & -4.8 \\
\hline
\end{tabular}

Note: Means significantly different from the other groups are marked according to the Fisher least significant difference test: $* * *_{-} \mathrm{p}<0.01, *_{-} \mathrm{p}<0.05, *_{-} \mathrm{p}<0.1$. The underlined $\mathrm{p}$-levels indicate the most relevant tests considering data distribution. Source: Authors' calculations based on ${ }^{13}$.

We also conclude that large economies are more closed both by exports and imports than 
medium-sized economies. Small economies are more open than medium-sized economies by imports only. This results in the fact that large and medium-sized economies tend to have trade surplus or balanced trade, while small economies suffer from substantial trade deficit. Thus the marginal benefits from the home market effect decrease, i.e. in order to balance foreign trade a country usually must have at least a medium-size of economy. There is a similar dependence of current account balance on economy size, but small economies contrast less with the rest of the countries because of incoming current transfers.

In the period considered small economies experienced faster imports and exports growth with the exports growing faster than imports. Medium-sized economies had faster growing imports than exports. But we must note that negative correlations between the log of GDP on one hand and exports or imports on the other hand were registered in 2009-2016 (-0.16 and-0.21). In 2001-2008 they were close to zero (0.01 and 0.07$)$. Therefore the data evidence rather in favor of higher foreign trade volatility in small economies.

Improvement of terms of trade took place mainly in small economies, but at least one of the nonparametric tests (median test) does not prove it. The mean values for large and medium-sized economies are not representative. Therefore we abstain from a definite statement about the effect of country size on foreign trade prices.

In 2006 China had a typical for large economies trade openness (65.6\% GDP), but as its economy has grown since that time and China has turned into a giant economy with a large domestic market, its trade openness decreased. Nevertheless the giant economy of the US has even lower ratio of foreign trade to GDP (29\%). Russia is a more closed economy than an average large economy. There was also downward trend, although less distinct. In 2006 China was a more open economy to foreign trade than Russia. Nowadays the situation is different. Therefore we can assume that Russia would rely more on trade with China than vice versa.

China and Russia have almost equal merchandise trade to the GDP ratio, which is smaller than in an average large economy. But unlike China Russia is more open to trade in services, its value is closer to the mean value for large economies. In both countries decrease in trade openness happened due to merchandise trade. Trade in services to GDP ratio especially in Russia turned out to be more stable in recent years. Exports and imports in China and Russia are below the average in large economies, except exports in Russia which differ less from the mean in large economies.

Both countries have better than average trade balance, especially Russia, although it has decreased substantially since 2006, especially in China. But this is natural for China as an economy with a large share in the global GDP. It cannot export as much as before because of relative shrinking of the "Rest of the World economy". The current account balances are also better than in other large economies with the downward long-term trend.

Exports (in constant prices) growth in Russia was below average in recent years, while imports even decreased. The World Bank does not publish the relevant data for China. Terms of trade in China restored after decrease in 2010-2011. But Russia suffered from worsening its terms of trade especially in 2015 due to the falling fuel prices. Thus China performed better and Russia worse than an average large economy.

The two-way ANOVA provided no evidence that trade openness, current account balance and terms of trade have a significant effect on economic growth. But there is a marginal significance of interaction effect between economy size and the ratio of imports to GDP. The small economies (only in developing countries) with imports less than 50\% GDP experienced slower economic growth (with the mean /median GDP (per capita) growth $0.7 \% / 1.1 \%$ ) in comparison to similar countries that are more open to imports $(2.0 \% / 1.5 \%)$. The effect of import dependence in mediumsized and large economies is different (negative), but insignificant. Fast growing small economies $(1.9 \% / 1.5 \%)$ had large trade deficit (below -7\% GDP), unlike slower growing economies 
$(0.5 \% / 0.9 \%)$, which tended to have small trade deficit or even surplus. There is no significant effect in larger economies.

All types of economies with exports growth higher than $4.3 \%$ experienced usually faster economic growth $(1.9 \% / 2.1 \%)$ in comparison to countries with slower exports growth $(1.0 \% / 0.9 \%)$. Also all types of economies with imports growth higher than $4.2 \%$ experienced usually faster economic growth $(2.0 \% / 2.4 \%)$ in comparison to countries with slower imports growth $(0.9 \% / 0.9 \%)$. In case of exports growth there is a theoretical background for its positive effect, since net exports are a component of GDP. But in theory imports contribute negatively to the GDP. Therefore we assume that GDP growth influences imports, i.e. growing economies tend to have growing demand for imports. Also we must note that since small economies usually have faster exports growth, they actually realize positive effect of exports growth more often than larger economies.

We also made a regression model for the effect of exports growth (standard errors are in brackets):

$$
G D P g r=1.762-0.027 G D P p c+0.08 E x p
$$

GDPgr is the average GDP per capita growth in a country, GDPpc is the GDP per capita in thousand dollars in 2015 (PPP method), Exp is the annual exports growth. Linear regression turned out to fit better than regression based on variables in logs. All the regression coefficients are significant at $\mathrm{p}<0.01$. The number of cases is 157 . The model supports the results of the ANOVA, it explains the influence of the factors, but is not efficient for forecasting because of low $\mathrm{R}^{2}$ value (0.13).

It shows that economic growth decreases on average by 0.1 percentage point when GDP per capita increases by about 4 thousand dollars. Each 1\% of exports growth increases GDP growth by $0.08 \%$. But the effect is even stronger for medium-sized economies $(0.17 \%)$ and large economies (0.24\%).

\section{Conclusions}

Small economies are the most open to trade, especially to imports and to trade in services, and are more likely to have trade deficit. All types of economies can benefit from fast exports growth. Russia and especially China are less open economies than most of the large economies and succeeded more in maintaining their trade surpluses. Both economies seem to differ from smaller economies by foreign trade trends even more than other large economies, which is logical as these countries are bigger than an average large economy. Despite the export-oriented strategy is more efficient for economic growth, it is not easy to sustain it under lower energy prices (case of Russia) or when a country turns into a giant economy (case of China). Therefore some slowdown in economic growth is quite natural under these circumstances.

\section{Acknowledgements}

This article is supported by the youth program of University Humanities and Social Science Foundation of Jiangxi. (No.JJ17215).

\section{References}

[1] Rose, A. K., Size really doesn't matter: in search of a national scale effect. Journal of the Japanese and International Economies, 2006, 20 (4), P. 482-507. 
[2] Alouini, O. and Hubert P., Country size, growth and volatility. Document de travail 2010-18. Observatoire Françaisdes Conjoctures Économiques, Paris, 2010.

[3] Egger, H. and Egger, P., Outsourcing and trade in spatial world. Working paper 1349. CESifo, Munich, 2004.

[4] Easter, Ch., Small states development: a Commonwealth vulnerability index. The Round Table: The Commonwealth Journal of International Affairs, 1999, 88(351), 403-422. DOI: 10.1080/003585399107947.

[5] Alesina, A. and Wacziarg, R., Openness, country size and government. Journal of Public Economics, 1998, 69 (3), 305-321. DOI: 10.1016/S0047-2727(98)00010-3.

[6] Pieretti, P., Zanaj, S. and Zou, B., The long run survival of small nations: a dynamic view. Working paper 437. Bielefeld University, Bielefeld, 2010.

[7] Vujakovic, P., How to measure globalisation? A New Globalisation Index (NGI). Working paper 343. Österreichisches Institut für Wirtschaftsforschung, Wien, 2009.

[8] Amin, M. and Islam, A., Imports of intermediate inputs and iountry size. Policy research working paper 6758. The World Bank, Development Economics, Global Indicators Group, Washington DC, 2014.

[9] Docquier, F. and Schiff, M., Measuring skilled migration rates. The case of small states. Policy research working paper 4827. The World Bank, Development Research Group, Trade Team, Washington DC, 2009.

[10] Nyamtseren, L., Challenges and opportunities of small countries for integration into the global economy, as a case of Mongolia. Dresden discussion paper in economics 13/04. Dresden University of Technology, Dresden, 2004.

[11] Krugman, P., Scale economies, product differentiation, and the pattern of trade. The American Economic Review, 1980, 70(5), 950-959.

[12] Okubo, T., Picard, P. and Thisse, J.-F., on the impact of competition on trade and firm location. CREA discussion paper 2014-05. Center for Research in Economic Analysis, University of Luxembourg, Luxemburg, 2013.

[13] World Bank, World development indicators; http://data.worldbank.org/data-catalog/world-developmentindicators (accessed on 22 February 2018). 